\title{
EXPERIENCES OF MICROCREDIT BENEFICIARIES: A STUDY OF RURAL WOMEN IN DISTRICT SHEIKHUPURA, PAKISTAN
}

\author{
Tauqeer Hussain Shah \\ Assistant Professor (Visiting Faculty), Department of Environmental Science, \\ International Islamic University, Islamabad, Pakistan \\ tauqeer_hashmi@hotmail.com \\ Huma Butt \\ Lecturer, Department of Sociology, \\ International Islamic University, Islamabad, Pakistan \\ huma.butt6@gmail.com
}

\begin{abstract}
Based on the constructivist epistemological point and qualitative research design, the present study attempts to explore the experiences of rural women about microcredit programs. The population of this study comprised of women beneficiaries of microcredit dwelling from District Sheikhupura, Pakistan. The purposive sampling technique has been used to select respondents for in-depth interviews. The researchers have started fieldwork with some broader questions in their minds as informed by the grounded theory approach (Charmaz, 2006; Jerolmack, 2007; Strauss \& Corbin, 1990). These in-depth interviews and field observations enabled the researchers to draw some new themes and inferences. The researchers have included all these themes and inferences in their interview guide for further interviews. A total of 21 in-depth interviews have been conducted which include the 7 interviews at the initial stage of data collection. It was observed that microcredit has some positive as well as some negative consequences on the lives of the recipient. It was positively linked with women's economic empowerment, improvement in their well-being, decrease in intimate partner violence, positive influence on the member's own and their children's health, education, and nutrition patterns. However, some of the respondents said that microcredit did nothing with their empowerment rather it indulge them in extreme poverty and increased male dominance at the household level.
\end{abstract}

Keywords: Microcredit, Women Empowerment, Intimate Partner Violence, Patriarchy, Extreme Poverty, Money Lenders

\section{INTRODUCTION}

A significant population of Pakistan is that of females (Iftikhar et al., 2009). Most of the rural females are housewives and are engaged in agricultural activities (Ishaq \& Memon, 2016, p. 1; Arshad et al., 2013). They also engaged in different household tasks that are energy-consuming and play a major role in the economic uplift of the rural areas (Lodhi et al., 2006; The Gazette of Pakistan, 2005; Iftikhar et al., 2009). Only a small portion of these women is a part of some other income-generating activities at the household level or the local level. The main source of rural women's income generation other than livestock and agriculture is small business and trade at the village level, for example, handicraft, embroidery, tailoring, weaving, leatherwork, pottery, ceramics, and food processing activities (Jabeen et al., 2020). These home-based income-earning activities are very important for their household expenses (Waheed, 2009; Zaman, 2009; Suguna, 2006; Khan, 2008).

Most of these working women belong to the lower socio-economic class. They have skills but due to lack of economic resources and financial constraints, they cannot start any income-generating activity. Moreover, in some cases, due to lack of collateral, they are unable to get access to the microcredit facilities provided by the formal sector because they are being considered as "dangerous borrowers" (Khan et al., 2017, p. 637). However, plenty of literature also reflects that microcredit played a pivotal role in poverty reduction and the socio-economic well-being of low-income consumers (Bashir et al., 2010; Ullah et al., 2020). Keeping in view the above-mentioned arguments, the present study is an attempt to further explore the skilled rural women's experiences of microcredit 
utilization in district Sheikhupura, Pakistan. Furthermore, the present study is based on a qualitative research design that facilitates getting an emic view instead of an external explanation (Hesse-Biber \& Leavy, 2006).

The major research question of the present study is to explore how rural women describe their experiences regarding microcredit utilization. This research question is further divided into various dimensions, for example, how it is beneficial for economic empowerment of rural skilled women, how it plays role in the social well-being of the clients and their families, how it is linked with the self-respect of the clients. Moreover, it will further explore whether or not there is any link between microcredit utilization and reduction in domestic violence against women. Similarly, the present research will explore how microcredit is misused and creates problems for the clients. We assume that the present study will address these queries and we will come back to these questions in the analysis section.

\section{REVIEW OF LITERATURE}

The following text takes an account of the available scientific literature in the field of microcredit and how it is linked with poverty reduction strategies. Moreover, it also sheds light on how it is linked with various spheres of women's lives. Plenty of literature is available on the functioning and utilization of microcredit for poverty reduction. Some studies stated that microcredit has facilitated the business of poor people especially rural women and enhanced their capacity to initiate or expand income-generating activities (Lodhi et al., 2006; Khan, 2008; Waheed, 2009). However, some scholars have reported that microcredit had some negative impact on women's empowerment (Weiss \& Montgomery, 2005; Morduch, 2000; Malik \& Luqman, 2005). According to the opinion of those researchers who are in the favor of microcredit, it can enhance the current business of the poor (Basher, 2009). The majority of those rural women engaged in agri-business can enhance their rural productive activities by microcredit (Waheed, 2009). The researchers also pointed out that access to credit facilities is an important determinant to measure the degree of the economic contribution of women. Women's economic contribution to their families increases their respect and importance among family members.

Vyas and Watts (2009) found that growth in the economy and poverty alleviation affect intimate partner violence. In their study, they observed a strong protective association between violence and assets wealth and concluded that the more the assets wealth of women the lesser the chances of intimate partner violence. Similarly, women's access to resources is well connected with their health-seeking behavior and contraceptive use (Develtere \& Huybrechts, 2005; Kadir et al., 2003; Amin et al., 1998; Levin, 1994). Likewise, microcredit has a strong association with the education and nutrition of the children of the borrowers (Chowdhury \& Bhuiya, 2004; Kabeer \& Mahmud, 2004; Quisumbing \& Maluccio, 2003; Littlefield et al., 2003; Develtere \& Huybrechts, 2005). Littlefield et al., (2003) took a sample of 200 respondents for their research in India. They observed that microfinance allows poor people to protect and increase their sources of income. It was observed that the client's children have more enrolment and stay longer in school as compared with non-clients. Apart from this direct effect on school enrolment, the Grameen takes direct measures such as scholarships (Steele et al., 1998; Littlefield et al., 2003).

Moreover, an increase in the consumption standards of women is linked with their income. Higher income mostly leads towards higher standards of consumption. In his study, Waheed (2009) argued that microcredit is projected for investment to improve the well-being of poor people in rural productive activities. The credit increases the income of poor people and consequently affects consumption. Furthermore, microcredit is linked with women's control over resources and food security. Guha-Khasnobis and Hazarika (2007) have conducted a study on household access to microcredit and children's food security in rural Malawi. They have used the data from the 1995 Malawi financial markets and food security survey. The study showed that women's access to microcredit plays a role in children's food security and their control over resources. The women's access to microcredit improves the young girls' nutrition.

Contrary to the above-mentioned scientific literature, some researchers have focused on the opposite point of view. They argued that microcredit is not a success story rather it increases the vulnerability of poor people. For instance, Rugimbana and Spring (2009) have pointed out that although microfinance institutions (MFIs) are working for poverty alleviation among women through 
enterprise development. But MFIs in Africa have often failed and many even cause more harm than good. Misuse of loans was also extensively reported by some researchers. This also indicates a weak appraisal of the business of the borrowers by the staff of MFIs because they are interested in maximum disbursement of loans regardless of its proper utilization. As a result, borrowers get money and spend it on their non-business activities. The same was observed by Johnston and Morduch (2007) in their study on the measurement of the impact of microcredit on household income in Indonesia. The results proved that borrowers spent their loan money on non-business activities as school fees for their children, medical treatment, construction and maintenance of their homes, daily consumption needs, and other expenses of their social activities.

As the demand for repayment of loans by MFIs is very high, the borrowers cannot pay it from their resources or they have to sell their assets to repay the installments (Mosley, 2001, p. 101; Haq \& Kamran, 2009). Inflexible enforcement mechanism "of loan obligations resulted in some borrowers, especially amongst those who had taken only one loan, being made worse off" (Copestake et al., 2001, p. 81). Complex documentation and procedure of loan disbursement of MFIs is another factor to exclude poor people from the microcredit program. Due to lack of education, poor rural women are unable to understand and follow the official procedure. Moreover, male dominance in the decisionmaking process at the household level is also linked with the misuse of microcredit. Males compelled their household women to get a loan from MFIs and women hands it over to their males for their personal use (Goetz \& Gupta, 1996). As a result, the prime objective of poverty reduction through microcredit is to fail. Misuse of micro-credit in non-business activities has also been reported in some studies (Iqbal et al., 2015). The pressure of the male family members on the female is a significant factor that forces women to apply for microcredit. Microcredit is not always a striking source for poverty alleviation. Some development experts claim that microcredit programs are not intended to help poor people. For example, Chowdhury (2009) argued that both formal and informal financial sectors failed to serve the poor people, because the collateral, giving preference to high-income clients, and big amount of loans excluded poor people from their list. He stated that the bureaucratic structure and lengthy process of provision of loans in the formal sector keep poor people away. The informal sector also failed to support the poor. Excessive interest rates and exploitation through collaterals are major restrictions in the informal financial sector (Duggan, 2016).

In sum, the above-mentioned literature reveals several aspects of microcredit in the context of poverty reduction strategies and its impact on socio-economic dimensions of women's lives. It narrates that it is positively linked with economic empowerment and the social well-being of women, borrowers, and their children's health. It is also positively associated with the education of the children of the borrowers and nutrition patterns. However, it also reflects the increasing males' dominance at the household level and creating an economic burden on already marginalized people. The above-quoted researches are very important in the context of the present research because we assume that the rural women, only the sample of the present study, may face similar experiences after availing themselves the opportunity of the microcredit program. In this context, we expect that these themes will be further discussed in the analysis section concerning the empirical evidence from the field of the present study. The following section describes the materials and methods employed in the present study.

\section{MATERIALS AND METHODS}

A constructivist epistemological paradigm and qualitative research design are employed in the present study. The population of this study consisted of those women who availed the opportunity to get a loan from some microcredit organization in the rural areas of district Sheikhupura, Pakistan. Access to the field is very challenging in qualitative research and requires a very careful strategy to execute research that ensures the safety of the researchers as well as the respondents (Riese, 2018). The respondents of the present study were approached through the field staff of a local microfinance institute (MFI). The researchers ensured all professional research ethics in terms of prior permission for an interview as well as informed consent while recording of interviews; therefore, after getting permission the data has been collected (American Sociological Association, 2018).

The respondents were selected by applying non-probability sampling and, within nonprobability sampling; the purposive sampling technique has been used to select respondents. In-depth interviews were conducted as it provides a chance for the respondents to express their views about 
their important matters (Hesse-Biber \& Leavy, 2006). The researchers have started fieldwork with some broader questions in their minds (Shamarz, 2006; Jerolmack, 2007; Strauss \& Corbin, 1990). The researchers have conducted 07 interviews in the initial stage of the data collection for the development of new themes and inferences for further interviews. These in-depth interviews and field observations enabled the researchers to draw some new themes and inferences. The researchers have included all these themes and inferences in their interview guide for further interviews. A total of 21 in-depth interviews have been conducted including 7 interviews at the initial stage in this research. The researchers stopped further interviews until approaching the saturation point (Charmaz, 2006). The recorded data were transcribed into English from Punjabi and interpreted under different themes. Early observation in the field and memo writing have facilitated the researchers to create scientific text under different themes and inferences (Hesse-Biber and Leavy, 2006; Charmaz, 2006).

\section{RESULTS AND DISCUSSION}

This section presents the empirical evidence from the study area of the present research. It is further divided into various sub-sections according to the themes and categories identified from the data.

\section{Women's Economic Empowerment and Emancipation from Local Money Lenders}

Economic empowerment of women is linked with achieving equal access and control over economic resources (Hunt \& Samman, 2016, p. 7). In the past few years, it has become the priority area for sustainable development around the globe (Akhter \& Cheng, 2020). However, in the case of developing countries, gender inequality has been detected as the main hindrance to the progress of women (Akhter \& Cheng, 2020). In the present study, women's economic empowerment has emerged as a key theme during the process of data analysis. The participants narrated their experiences in this regard as one respondent told that:

Microcredit has facilitated our income-generating activities. MFI has opened opportunities for poor women. No one can facilitate you now-a-day. Now due to this facility [of microcredit], mostly women had started some income-generating activities [...] like some have breeding buffalos and some had started embroidery.

Similarly, the data also reflects that expansion of business through microcredit not only facilitated the borrowers but also indirectly provided work opportunities for non-beneficiaries as well. This situation is explained by another respondent:

My business boosted up when I got microcredit from MFI. Now, I am financially independent [...]. It has decreased my economic dependency on others. I had expanded my business and now I hired some other women for my work. This has provided an opportunity for others as well.

During interviews, the respondents also described that microcredit facilities by MFI in their local area also facilitated them to get rid of local money lenders. In district Sheikhupura, many local money lenders are providing financial services to local people. These money lenders are those traders or investors who are working in small and medium enterprises at the village level. Due to the lack of formal microcredit-providing institutions in the public or private sector, people are dependent on these local money lenders. As there is no competitor in this area, these local money lenders are charging a high rate of interest on their credit amount. Moreover, due to the high rate of interest, people are unable to pay back the original amount. As a result, they are captive in this system and local money lenders exploit them.

According to the data of the present study, it is estimated that MFI provides them a big relief as MFIs are working in this area since 2005; they are also partner organizations of the Pakistan Poverty Alleviation Fund. Before the operation of these MFIs, the only source of credit was local money lenders as mentioned above. However, now people are satisfied due to the microcredit scheme started by these MFIs. A major reason for their satisfaction is the relatively low-interest rate of MFIs as compared with local money lenders.

One respondent replied:

We have gotten rid of the captivity of these local money lenders. MFI has provided us with better service. Now, we can easily get a loan and pay it back. This is a good sign for us. 
Furthermore, in the case of MFIs, the official procedure of loan disbursement is client friendly as there is no financial collateral. In the appraisal program of the MFI working in the area of the present study, there is social collateral instead of economic collateral. In this procedure, women have to organize a group of 15 to 25 clients. All women know each other, and they can establish a small group within their locality. They further have to choose a group leader among the members. Each member gives a guarantee for the return of the loan. They also assure that if a client of their group fails to pay the monthly installment, in this case, then the whole group will be responsible to pay on her behalf. This social collateral exerts moral pressure on every member and they are vigilant to pay monthly installments on the due date. One respondent replied:

We know each other. All are living in this area for a long time. We have no threat that any person will escape after getting a loan. We all are responsible to pay back the full amount in such a case.

As mentioned above, the low-interest rate of MFI is the main reason for borrowers' satisfaction. They argued that due to the low-interest rate, it is easy for them to pay back the borrowed amount as monthly installments. One respondent argued:

Now I can easily pay an installment every month. The interest rate of MFI is comparatively low as compared with that of the local money lenders.

Similarly, the data of the present study also reveals that the microcredit facility by MFI also facilitated the borrowers to get control over their products. They can directly negotiate with merchants or traders to sell their products or to purchase the raw material. Earlier, it was controlled by some mediators, which is discussed in the following text.

\section{Emancipation from Mediators/Brokers}

In the rural areas of district Sheikhupura (by the sample of the present study), it was observed that most women are engaged in embroidery and handicraft, which is locally known as Adda and they are adept in this art. While working they also required some expansive stones, needles, and clothes are required as raw material. However, due to a lack of financial resources, these rural women are unable to purchase all these required materials. Moreover, as these items are available in Lahore city, so, distance is another negative factor that hinders these skillful women because they cannot afford the fare to travel to Lahore. Likewise, most of these rural women do not know about particular markets to purchase all this stuff. So, this gap is bridged by some mediators or brokers who are working in this area as informed by the respondents. They provide required material to these skilled women for embroidery and handicraft, as a result, these skilled women have bound to sell their products to these mediators or brokers. These mediators or brokers pay less money to these rural skilled women for this work as compared with the rate of the market. These mediators then sell all these products in different markets in Lahore at a very high cost.

During fieldwork, some of the respondents said that they know their exploitation but due to lack of finance they cannot resist. However, after the establishment of these MFIs in their area, now they have credit facilities. It is also found that women's exposure to the market can enhance their confidence as well. One respondent said:

Before these MFIs, I was unable to purchase the required material from Lahore. The main reason was lack of money. So, I have no option to accept the conditions of these mediators. But now I can purchase all relevant material on my own as I have sufficient money which I have got in the form of credit.

Similarly, another respondent replied:

Now no one can exploit me. As I have sufficient amount for shopping of necessary

items for my business. I can look after my business; I do not need these mediators.

\section{Social Wellbeing and Reduction in Domestic Violence against Women}

The notion of wellbeing is more useful when it is used in the social context (Teghe \& Rendell, 2005, p. 2). An increase in income-generating activities is also linked with the social wellbeing of the respondents because it enhances the living conditions, health facilities, and their children's education (Hoque, 2008). These savings enable them to increase household expenditures on the well-being of themselves, their children, and family as well (Develtere \& Huuybrechts, 2005; Littlefield et al., 2003; Mayoux, 2002; Islam \& Choe, 2009). One respondent said that: 
After the death of my husband, it was very difficult for me to manage the expenses of the education of my children. I was very worried and thought of discontinuing the education of my children. In those days, someone told me to get a loan from MFI and start some business. I did so and I started the trade of rice. Now, I can easily manage all these expenses. My children are also going to school.

Similarly, dowry is a very strong customary practice in the province of Punjab, Pakistan. Most of the respondents told that microcredit was very helpful for the marriage of their daughter. From savings of the business, they had managed the expenses of dowry as one respondent told:

I have used the profit for the marriage of my daughter. The savings were sufficient for dowry and other expenses of marriage. My husband has also contributed and we both have successfully managed the marriage ceremony.

Some researchers argued that microcredit is a source of safety for women. It promotes several aspects of the life of women that includes different aspects of welfare, empowerment, motivational, and attitudinal changes among the program participants (Amin et al., 1998; Basher, 2007). When women contribute to the family income, their respect and status also increase because husbands pay regard to them for their contribution to the household income. So, it can be inferred that reduction in domestic violence against women is linked with microcredit schemes. One respondent argued:

Before submission of the application for microcredit, I got permission from my husband. He allowed me to get the loan. Now he never gets annoyed with me. He never uses harsh words to me and he gives me respect as well.

The study also found that borrowers enjoy social respect in their community because people consider them as a source of information; this is also discussed in the following text.

\section{Source of Information and Social Respect}

MFIs have established some community groups for their clients. It has been observed during the fieldwork that some women were working as center managers and group leaders in these community groups. These women were a great source of information regarding the process of loan disbursement because they were familiar with the process of application submission and further procedure of loan disbursement. So, most of the desired clients and their families consulted them for information. Besides, these center managers and group leaders are enjoying social status as people pay them to regard as they are dependent on them for information. These findings are supported by some previous studies which argued that microcredit is also linked with the social status of the borrowers (Gobbi, 2005; Kabeer, 2001). As a center manager of MFI replied:

Now every person on my street pays Salam (greetings in Islam) and I enjoy it very much. Even elder women pay me respect, in which, some women are as older as my mother. This is because people know that they can get information from me regarding a loan.

The study also explained inquisitive as well as contrasting results. In the above-mentioned text, it is discussed that microcredit is a source of economic empowerment, emancipation from local money lenders and brokers, social wellbeing, reduction in domestic violence against women, source of information, and social respect. However, some of the respondents argued that this microcredit scheme in their area has nothing to do with their welfare rather it is more problematic for them. This notion is reflected in the following text.

\section{Philosophy of Poverty Alleviation and Misuse of Loan}

The philosophy of the microcredit scheme of MFIs is the provision of financial assistance to those working women who are skilled but due to lack of financial resources, they are unable to start their business or expand their income-generating activities. However, during fieldwork, it is observed that practically it is not happening. Some of the respondents have got a loan for some other purposes which were not linked with their income-generating activities. One respondent told her story:

The outside wall of my house was damaged in the last rainstorm. I have taken a loan from MFI and I spent it on the construction of that wall. It is important for me to construct a boundary wall for security purposes. As my daughters are young and a house without walls can be vulnerable to any mishap.

Similarly, another participant of the present study argued as: 
I spent a loan on the construction of stairs of my house. I told them that I need money for my business but actually, I had spent it on the construction of stairs. However, officially, I have shown business activities in documents of MFI.

During the interview, one respondent told:

When I got a loan for the first time, I handed it over to my husband for his business. Now he is planning to go abroad. So, this time I shall apply for a loan for his passport and other expenses.

Another respondent replied:

I have taken a loan and handed it over to a female. She requested me to give her money. So I did so.

In the above-mentioned responses of the respondents, it can be concluded that there might be two possible reasons for this misutilization of microcredit. Firstly, the social mobilizers or other management of the MFI working in the field area of the present study are not well-trained to conduct a social and economic appraisal of the applicants. Secondly, they deliberately overlooked the possibility of misuse of microcredit for the reason that they are bound to disburse a certain amount quarterly. If they fail to do so, then it may be a negative impact on their job efficiency. As a result, to gratify the higher management, they somehow fulfill their quarterly target of disbursement.

\section{Patriarchy and Loan Utilization}

Generally, MFIs had started microcredit activities for skilled working women. However, data of this study shows that, in most cases, women cannot get a loan without the permission of their male family members. The main reason behind this notion is the patriarchal structure of Pakistan society (Hadi, 2017). These male members can be a father, a husband, and a son. Ideally speaking, the purpose of microcredit for women is to enhance their empowerment at the household level. But the male family members forced them to act according to their instructions. Females are still dependent on their male family members and act as a puppet in their hands. Some respondents told that they have got microcredit due to the pressure of their male family members. As one respondent explained:

My father pressurized me to take out a loan because he needed some money for his

personal use. I got a loan and handed it over to him.

Similarly, another respondent said:

My husband is a truck driver. He has forced me to get a loan from MFI. I did so and

handed the money over to my husband.

Likewise, another respondent shared her story:

I am forced to hand this money to my husband; He is running a milk shop. I assured

the management of MFI that I need credit for my own business. But actually, it was not true. Now, her husband responsible for the payment of its installments.

In the local culture of Punjab, women voluntarily accept the authority of their male family members in their day-to-day life matters. They consider it as a value and they have no urge to change this customary practice. Most women consider it a very sacred issue in terms of religion. During an interview, when I asked a respondent about the importance of getting permission from male family members, she explained:

Gentleman! How are you talking? Holy Prophet (PBUH) preached that women should obey their husbands. It is very important to get the permission of male family members before any activity.

Another respondent said:

It is very important to get permission from the husband. It depends on his decision. If he does not like we can do nothing.

The data of the present study reveals that some women have taken a loan and simply handed it over to their husbands for their business or personal use. They do not know the purpose of microcredit schemes and they just obey their husbands in this matter. The male family members simply take the responsibility to pay back monthly installments. Women have nothing to do in this regard. Some women told that their husbands inform them about the utilization of credit but they do not know further details. One respondent explained: 
My husband asked me to get a loan because he wanted to buy a buffalo. I have taken a loan and handed it over to him. I do not know from where he had bought that buffalo.

Other than patriarchal pressure, the high-interest rate is another factor that is negatively affecting the borrowers. This is discussed in the following text.

\section{High-Interest Rate}

The high-interest rate of microcredit organizations is a hindrance that leads people to criticize the policies of organizations. Sometimes it plays havoc with the assets of borrowers (Yusoff \& Shanon, 2000). The data of the present study shows the difference of opinion of the borrowers about the strategies and operation of microcredit organizations working in the rural areas of districtSheikhupura. However, there is a consensus of all borrowers on the point of the high-interest rate charged by the organization, even if they were satisfied that they got rid of the local money lenders. Though the interest rate of microcredit organizations was relatively less as compared with that of the local money lenders, however, the respondents have suggested that this interest rate should be further lower down.

\section{CONCLUSION}

The findings showed that microcredit has some positive as well as some negative consequences on the lives of the respondents. It was positively linked with women's economic empowerment, improvement in their social wellbeing, decrease in intimate partner violence, positive influence on the member's own and their children's health, education, and nutrition patterns. In contrast, some of the respondents told that microcredit did nothing with their empowerment rather it indulge them in extreme poverty. Further, male dominance at the household level in decision-making was also observed as an obstacle in rural women's enterprise development. After a holistic review of the literature and results of the present study, it can be concluded that theoretically speaking, poverty reduction strategy through microcredit and enterprise development is fine. However, practically, there is a need to improve the implementation strategies and operations of MFIs. As long as the MFIs continue to make it only profit-oriented and do not take it as a welfare project, its success is next to impossible (Mahmud, 2008). Despite all these factors, this program of poverty alleviation through microcredit is, after all, essential for the development of society, especially, for the betterment of income-generating activities of skilled rural women.

\section{REFERENCES}

Akhter, J., \& Cheng, K. (2020). Sustainable empowerment initiatives among rural women through microcredit borrowings in Bangladesh. Sustainability, 12(6), 2-19.

American Sociological Association. (2018). Code of Ethics. Washington, DC: American Sociological Association.

Amin, R., Hill, R., \& Li, Y. (1998). Poor women's participation in credit-based self-empowerment: The impact on their empowerment, fertility, contraceptive use, and fertility desire in rural Bangladesh. Pakistan Development Review, 34(2), 93-119.

Arshad, S., Muhammad, S., \& Ashraf, I. (2013). Women's participation in livestock farming activities. The Journal of Animal \& Plant Sciences, 23(1), 304-308.

Basher, M. A. (2007). Empowerment of microcredit participants and its spillover effects: Evidence from the Grameen Bank of Bangladesh. Journal of Developing Areas, 40(2), 173-183.

(2009). Promotional role of microcredit: Evidence from the Grameen bank of Bangladesh. Hoboken: John Wiley \& Sons Ltd.

Bashir, M. K., Amin, A., \& Naeem, M.K. (2010). Micro-credit and poverty alleviation in Pakistan. World Applied Sciences Journal, 8(11), 1381-1386.

Charmaz, K. (2006). Constructing Grounded Theory: A Practical Guide Through Qualitative Analysis. London: Sage Publications.

Chowdhury, J. (2009). The role of micro-credit in the alleviation of poverty: A Study of the Grameen bank in Bangladesh. Dhaka: University of Dhaka.

Chowdhury, M. R., \& Bhuiya, A. (2004). The wider impacts of BRAC poverty alleviation programme in Bangladesh. Journal of International Development, 16(3), 369-386. 
Copestake, J., Bhalotra, S., \& and Johnson, S. (2001). Assessing the impact of microcredit: A Zambian case study. The Journal of Development Studies, 37(4), 81-100.

Develtere, P., \& Huybrechts. (2005). The impact of micro-credit on the poor in Bangladesh. Alternatives: Global, Local, Political, 30(2), 165-189.

Duggan, C. S. (2016). Doing bad by doing good? Theft and abuse by lenders in the microfinance markets of Uganda. Studies in Comparative International Development, 51, 189-208.

Gobbi, M. (2005). Nepal and Pakistan microfinance and microenterprise development: Their contribution to the economic empowerment of women. International Labor Office, 3, 65-65.

Goetz, A. M., \& Gupta, R.S. (1996). Who takes the credit? Gender, power, and control over loan use in rural credit programs in Bangladesh. World Development, 24(1), 45-63.

Guha-Khasnobis, B., \& Hazarika, G. (2007). Household access to microcredit and children's food security in rural Malawi. Helsinki: World Institute for Development Economics Research.

Hadi, A. (2017). Patriarchy and gender-based violence in Pakistan. European Journal of Social Sciences, Education and Research, 10(2), 297-304.

Haq, M. Z., \& Kamran, M. (2009). Role of microcredit in women's empowerment. Master thesis within Business Administration. Jönköping University, Sweden.

Hesse-Biber, \& Leavy, P. (2006). The practice of qualitative research. London: Sage Publications.

Hoque, S. (2008). Does micro programs in Bangladesh increase household ability to deal with economic hardships. http/heapro.oxfordjournals.org/cgi/content/full/16/3/219

Hunt, A., \& Samman, B. (2016). Women's economic empowerment: Navigating enablers and constraints. London: Overseas Development Institute.

Iftikhar, N., Ali, T., Ahmad, M., Ashfaq, M. \& Haq, Q. (2009). Training Needs of Rural Women in Agriculture: A Case Study of District Bahawalpur, Pakistan. Pakistan Journal of Agriculture Science, 46(3), 200-208.

Iqbal, Z., Shaheen, S., \& Ahmad, H. (2016). Causes regarding failure of micro-financing: The study of Southern Punjab, Pakistan. European Academic Research, III(9), 9659-9671.

Ishaq, W., \& Memon, S. Q. (2016). Roles of women in agriculture: A case study of rural Lahore, Pakistan. Journal of Rural Development and Agriculture, 1(1), 1-11.

Islam, A., \& Choe, C. (2009). Child labor and schooling response to access to microcredit in rural Bangladesh. Australia: Monash University.

Jabeen, S., Haq, S., Jameel, A., Hussain, A., Asif, M., Hwang, J., \& Jabeen, A. (2020). Impacts of rural women's traditional economic activities on household economy: Changing economic contributions through empowered women in rural Pakistan. Sustainability, 12(7), 2-23.

Jerolmack, C. (2007). Animal practices, ethnicity, and community: The Turkish pigeon handlers of Berlin. American Sociological Review, 72(6), 874-894.

Johnston, D., \& Morduch, J. (2008). The unbanked: Evidence from Indonesia. The World Bank Economic Review, 22(3), 517-537.

Kabeer, N. (2001). Conflicts over credit: Re-evaluating the empowerment potential of loans to women in rural Bangladesh. World Development, 29(1), 63- 84.

Kabeer, N., \& Mahmud, S. (2004). Globalization, gender, and poverty: Bangladeshi women workers in export and local markets. Journal of International Development, 16(1), 93-109.

Kadir, M., Fikree, F., Khan, A., \& Sajan, F. (2003). Do mothers-in-law matter? Family dynamics and fertility decision making in urban squatter settlements of Karachi, Pakistan. Journal of Biosocial Science, 35(4), 545-558.

Khan, A. (2008). Tackling the failure of microfinance efforts through amalgamating microfinance with charity: Two variable alternatives in the context of Pakistan. Autralasian Accounting Business \& Finance Journal, 2(2), 19-33.

Khan, I. H., Bibi, S., \& Javaid, A. (2017). Solving poverty through management: Experience in Pakistan. European Online Journal of Natural and Social Science, 6(4), 637-645.

Levin, A. (1994). The effects of differential preferences in the household on the demand for maternal health care. USA: Johns Hopkins University.

Littlefield, E., Murduch, J., \& Hashemi, S. (2003). Is microfinance an effective strategy to reach the millennium development goals? www.ifmr.acin/cmf/wp. 
Lodhi. T. E., Luqman, M., Javed, A., \& Asif, M. (2006). Utilization of Micro-Credit by the female Community: A Case Study of Azad Jammu and Kashmir (Pakistan). International Journal of Agriculture \& Biology, 8(20), 175-177.

Malik, N, H., \& Luqman, M. (2005). Impact of micro credit on women empowerment: A review paper. Pak.J.Sci., 42(3-4), 100-105.

Mayoux, L. (2002). Microfinance and women's empowerment: Rethinking 'best practice'. Development Bulletin, 57, 76-81.

Morduch, J. (2000). The microfinance schism. World Development, 28(4), 617-619.

Mosley, P. (2001). Microfinance and poverty in Bolivia. The Journal of Development Studies, 37(4), 101-132.

Quisumbing, A., \& Maluccio, J. (2003). Resources at marriage and intrahousehold allocation: Evidence from Bangledesh, Ethiopia, Indonesia, and South Africa. Oxford Bulletin of Economics and Statistics, 65(3), 283-327.

Riese, J. (2018). What is 'access' in the context of qualitative research? Qualitative Research, 19(6), 669-684.

Rugimbana, R., \& Spring, A. (2009). Marketing micro-finance to women: Integrating global with local. International Journal of Nonprofit and Voluntary Sector Marketing, 14, 149-154.

Steele, F., Sajida, A., \& Ruchira, T. (1998). The impact of an integrated microcredit program on women's empowerment and fertility behavior in Rural Bangladesh. Population Council Working Papers, 115, 1-43.

Strauss, A., \& Corbin, J. (1990). Basics of Qualitative Research: Grounded Theory $\quad$ Procedures and Techniques. Newbury Park, CA: Sage.

Suguna, B. (2006). Empowerment of Rural Women through Self Help Groups. New Delhi: Discovery Publishing House.

Teghe, D., \& Rendell, K. (2005). Social wellbeing: A literature review. Queensland: Central Queensland University.

The Gazette of Pakistan. (2005). The Gazette of Pakistan. Islamabad: Government of Pakistan.

Ullah, A., Pinglu, C., Ullah, S., Aslam, N., \& Zaman, M. (2020). Role of microfinance in poverty alleviation in the least developed areas of Pakistan. Asian Economic and Financial Review, 10(12), 1430-1452.

Vyas, S., \& Watts, C. (2009). How does economic empowerment affect women's risk of intimate partner violence in low and middle income countries? A systematic review of published evidence. Journal of International Development, 21(5), 577-602.

Waheed, S. (2009). Does rural micro credit improve well-being of borrowers in the Punjab (Pakistan)? Pakistan Economic and Social Review, 47(1), 31-47.

Weiss, J., \& Montogmery, H. (2005). Great expectations: Microfinance and poverty reduction in Asia and Latin America. Oxford Development Studies, 33(3), 391-416.

Yusoff, A., \& Shahnon, S. (2000). Is microfinance working? Amanah Ikhtiar Malaysia in Perspective. The $7^{\text {th }}$ Tun Abdul Razak International Conference (Proceeding), Malaysia.

Zaman, H. (2009). Assessing the poverty and vulnerability impact of micro-credit in Bangladesh: A Case study of BRAC. Washington, D.C.: The World Bank. 